\title{
Internet meme as meaningful discourse: Towards a theory of multiparticipant popular online content
}

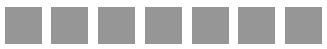 \\ Jakub Nowak \\ MARIA CURIE-SKLODOWSKA UNIVERSITY IN LUBLIN, POLAND
}

DOI: 10.19195/1899-5101.9.1(16).5

\begin{abstract}
Departing from the cultural studies semiotic approach, this chapter seeks to analytically review shifts in roles of media users given increasingly participation-oriented media tools. Drawing upon the re-interpretation of Stuart Hall's seminal encoding/decoding model of communication, the author proposes a theoretical concept of internet meme perceived as multiparticipant popular online content combining modalities of traditional (vertical and culture industryoriginated) and new (horizontal and peer-reproduced) modalities of media production and consumption. The author problematizes this concept by recontextualizing several aspects of Hall's theory: 1) theoretical appropriation of four stages of Hall's "chain of discourse" (messages' production, circulation, use, reproduction) to a new - highly converged - media environment; 2) ambiguous status of internet meme's authorship; 3 ) new contexts for analyzing internet memes, including: online pop-culture modalities, different strategies of "old" and "new" culture industries, Intellectual Property Rights policies.
\end{abstract}

KEYWORDS: Stuart Hall, internet meme, popular culture, communication theory, model of communication, internet.

\section{INTRODUCTION: NEW DISCOURSE OF NEW “INTERNETS"}

This article is a theoretical exploration of the significant changes in the sphere of new media usage. The process makes modern media studies both interesting and quite difficult, as the rapid development of new (digital) media is occurring alongside deep structural transformations in the media and culture industries. Social practices of media usage and participation in popular culture change as well. We witness peculiar new ways of media content distribution, more and more dense flows of culture industry products in various online environments in which pieces of movies, music videos, television programs and other culture industry and mainstream media products are remixed with user-generated content. We now face new (legal, cultural, market) status of authorship and new patterns and contexts of 
media usage that blur the border between pop cultural fun and serious (citizen, consumer) activism. Evidently, there is a new discourse out there, in the "internets", as Web users like to call it today. A new discourse in which media audiences, culture industry consumers, and participants in popular culture are not the same as they were even a decade ago.

This article is an attempt to conceptualize this new popular online discourse by analytically framing it with a model older than the internet as we know it. Departing from the cultural studies approach, I re-interpret Stuart Hall's seminal work on encoding/decoding television programs and theoretically re-appropriate his model to analyze popular new media content labeled as internet meme.

In particular, the main goal of the article is to propose a theoretical model of internet meme perceived as multiparticipant online content. In a wider perspective, I seek to analytically review shifts in the roles of media audiences given increasingly participation-oriented media tools. In other words, I want to analyze the ambiguous status of authorship of popular online content and its consequences. I hope that this article also contributes to media studies theory in general, as it discusses the utility of Stuart Hall's model in a radically different system of media production/consumption than the one originally analyzed by the British scholar.

While this is a theoretical paper, my considerations are based on my empirical studies on internet memes (Nowak, 2013a), and on writings by other scholars (Shifman, 2011, 2014; Jenkins et al., 2013; Burgess \& Green, 2009). Although the article does not offer a detailed analysis of any particular kind of internet memes, it contains examples chosen purposefully to support its main theoretical claims.

\section{WHAT ARE INTERNET MEMES? AND WHY INTERNET MEMES?}

I will start with a brief explanation of what internet memes are. Internet users ascribe the meme tag to observable audiovisual content, such as online images, e.g., screenshots from movies or music videos, user-published photos from social media websites and many more, or videos both: culture industry- and user-originated,

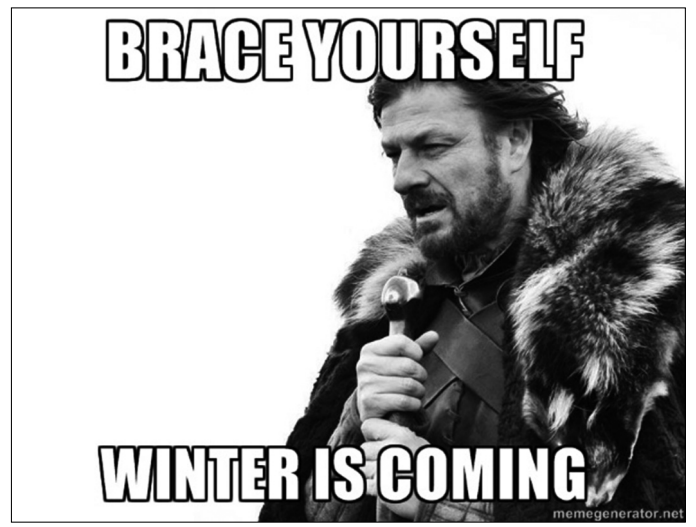

Figure 1. Imminent Ned (Brace Yourselves) meme

An image featuring the character Ned Stark from the HBO TV-series Game of Thrones and a sentence repeatedly appearing in the series. The meme is used to forewarn the impending arrival of a highly anticipated event or a product (usually by modifying Brace Yourself, $X$ is Coming template)

Source: http://knowyourmeme.com/memes/ imminent-ned-brace-yourselves-winter-is-coming (retrieved February 15, 2015). 
that are shared online by internet users through forwarding, linking, or copying (see Figures 1, 2, 3).

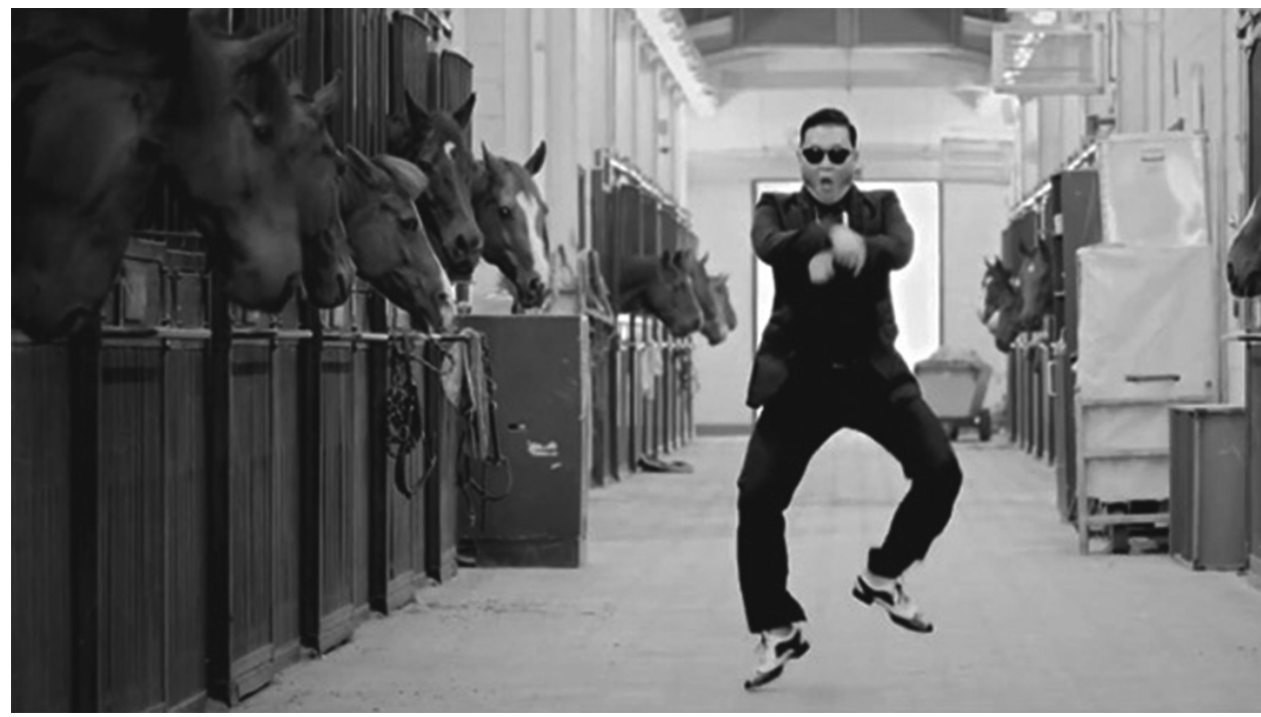

Figure 2. Gangnam Style: a music video to a pop single by the South Korean musician Psy

Source: http://knowyourmeme.com/memes/psy-gangnam-style (retrieved February 15, 2015).

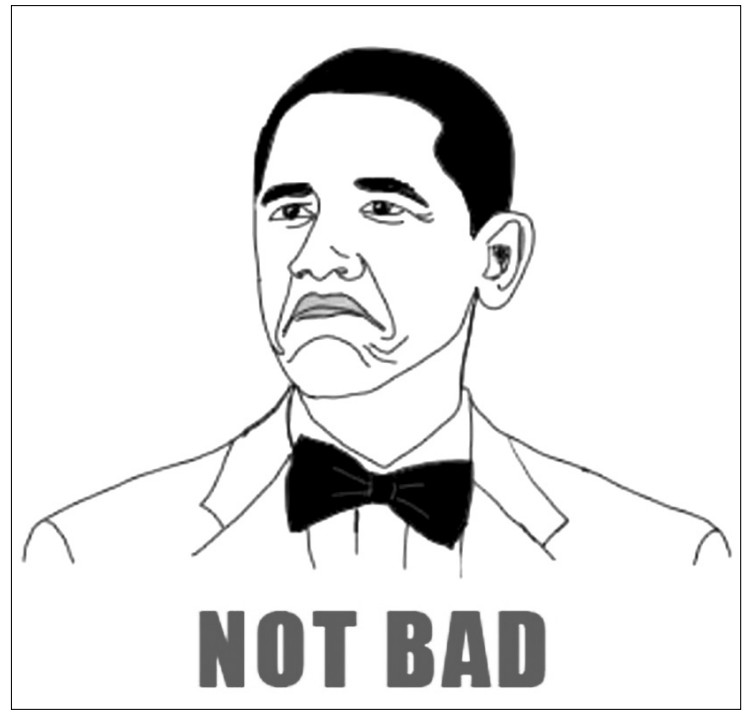

Figure 3. Obama Not Bad Face An image based on a press photograph of Barack Obama taken in May 2011. Used usually to express a positive evaluation of, or a positive response to something

Source: http://knowyourmeme.com/ memes/obama-rage-face-not-bad (retrieved February 15, 2015).

As Shifman puts it, these acts of redistribution are often accompanied by creating people's own versions of internet memes: web users use mechanisms of mimicry ("redoing" of specific texts by other people and/or by other means) and remixing (technology-based manipulation, for instance Photoshopping an image): 
Mimicry and remix are thus conquering the Web, and the term "meme" seems particularly suitable to describe this glut of reworks, as the concept - deliberately connoting "mimesis" - is flexible enough to capture a wide range of communicative intentions and actions, spanning all the way from naïve copying to scornful imitation. (Shifman, 2014, p. 22)

In other words, when a particular culture text such as an image or an audiovisual becomes a meme, it is distributed online in many variations in a spontaneous manner by various internet users who are aware that they deal with internet memes, for instance: a seemingly endless number of modifications of the Ned Stark character original depiction compose an "Imminent Ned" meme (see Figures 4, 5, 6). Therefore, the best way to approach internet memes is to perceive them not as single units but more as groups of texts with similar characteristics. Shifman defines internet meme as:

(a) a group of digital items sharing common characteristics of content, form, and/or stance, which (b) were created with awareness of each other, and (c) were circulated, imitated, and/or transformed via the Internet by many users. (2014, p. 41)

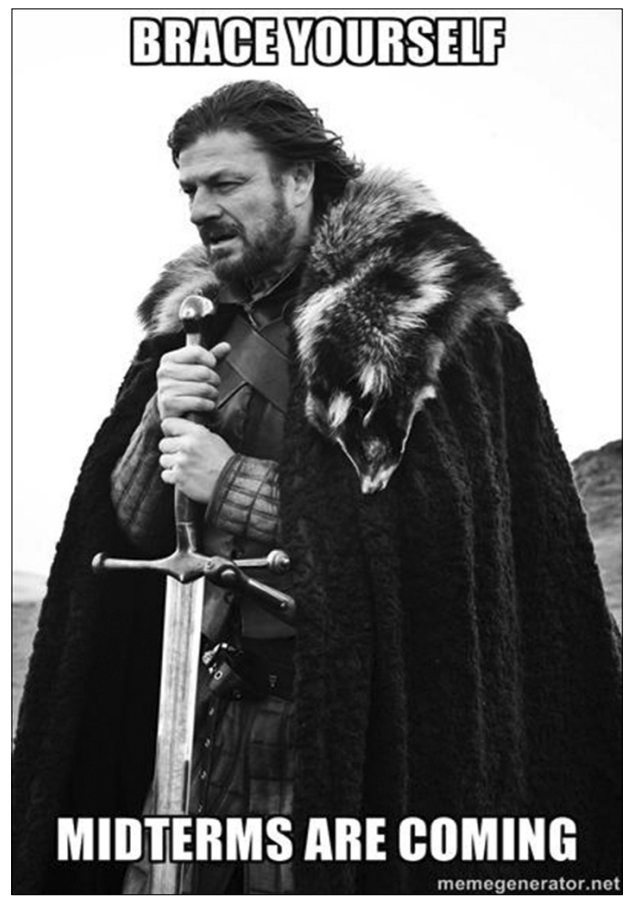

Figure 4. Imminent Ned memes produced by visual remixing of the original template (Midterms are coming)

Source: http://knowyourmeme.com/photos/181531-imminent-ned-brace-yourselves-winter-is-coming (retrieved February 15, 2015).

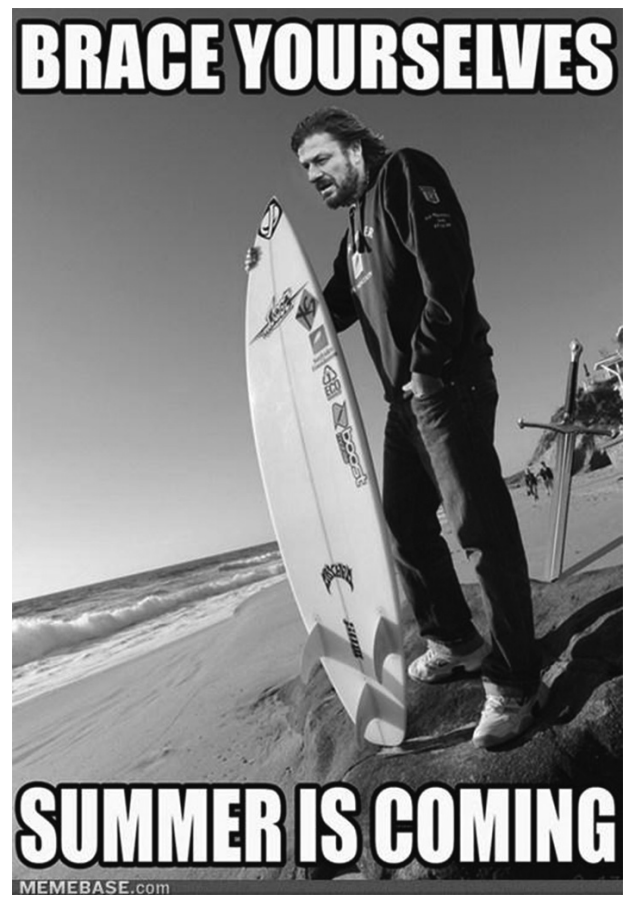

Figure 5. Imminent $\mathrm{Ned}$ memes produced by visual remixing of the original template (Summer is coming)

Source: http://knowyourmeme.com/photos/531225-imminent-ned-brace-yourselves-winter-is-coming (retrieved February 15, 2015). 


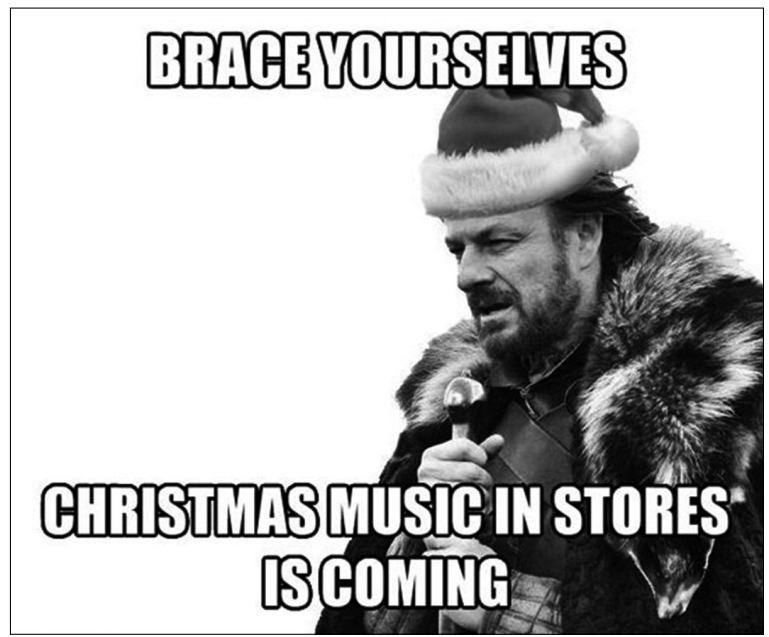

Figure 6. Imminent Ned memes produced by visual remixing of the original template (Christmas music in stores is coming)

Source: http://knowyourmeme.com/ photos/638489-imminent-ned-braceyourselves-winter-is-coming (retrieved February 15, 2015).

From the point of view of the political economy of new media, internet meme can be perceived as a popular culture text that is distributed online in a spontaneous, i.e., not culture industry-originated, manner (Nowak, 2013a). The term connotes a peculiar hybrid status of authorship and usage, but before going into more detailed analysis, two important preliminary remarks are necessary:

1) Internet memes as understood here are hardly connected to the concept of meme as described by meme theory scholars such as Richard Dawkins (1976) or Susan Blackmore (1999). The word meme is the same, obviously taken after Dawkins coined it when introducing his concept of memetics. Internet meme, however, works in the level of social practice and popular culture, not in the meta-level of an academic theory. In other words, when I write about memes, I do not use the theory of memes. I study internet memes as a particular kind of popular online content and from a completely different theoretical approach ${ }^{1}$.

2) The term labels both social practice and (very loosely related) theory, Shifman (2014, p. 9) even calls it a "conceptual troublemaker". One might ask then, if you can call it some other way, why use a term that can be misleading? Internet memes, of course, can be described by other definitions (for example as visual remixes). But the fact that particular content is labeled as internet memes brings the added value of meanings articulated by formal and thematic features representing the label itself.

In fact, this is my very point here: there is a coherent set of meanings embedded in a cultural object of internet meme (or, to use Stuart Hall's words, there is very distinct meaningful discourse of internet meme). I focus here on internet meme as a kind of media content (quite close to the semiotic meaning of media genre), arguing that there are formal and thematic features of online items read precisely as internet memes by people who produce, distribute and use them.

1 Of course internet memes can be analyzed with a meme theory, Shifman (2014), for instance, uses some aspects of Dawkins' approach in her study. I would argue, though, that theoretical approach in my paper fits well its general goal of reviewing shifts in roles of media audiences given new, more participatory, media. 
The general theoretical context of this article is framed by the interdisciplinary perspective of cultural studies focusing on how people create and share meanings. Cultural studies underline that everyday cultural practices are a significant sphere for both reproducing and questioning dominant ideologies (Williams, 1958; Hall, 1997; Fiske, 1989). Popular culture can thus be understood as the active process of generating and circulating meanings and pleasures within a social system at the point where two spheres meet: the first of culture industry products and the second of people's individual and collective everyday experience (Fiske, 1989).

New media have become the key tool and, metaphorically speaking, also sphere, of participating in popular culture. They are conducive to pop culture (or, to be more exact, conducive to the increasing number of diversified pop cultures) as they make participation in it more active and easy in terms of (re)producing and (re)distributing shared culture texts (Jenkins, 2006; Lessig, 2008; Jenkins et al., 2013; Burgess \& Green, 2009). They are also conducive to a social aspect of the process as they visualize its collective experience: internet users today are given the tools for easy reconstruction (remixing), horizontal redistribution, and discussion of texts produced by mainstream media and culture industry.

From this perspective internet memes are the essence of popular culture. They are popular media content (in terms of scale but also in the meaning given by the cultural studies approach) through which cultural and political identities can be communicated and negotiated. People produce and share memes not only to have fun (ludic motivations) but also to inform one another and to discuss things. Internet meme has become a significant modality of online discourse, a popular discursive tool for social, cultural, political, and consumer commentary (Nowak, 2013b; Shifman, 2014, pp. 119-150). ${ }^{2}$ For instance, they were an important language of the protest used in American anti-SOPA and European anti-ACTA protests by which common users raised awareness of the issues and mobilized support for online and street activities (see Figure 7) or were used to comment on the UkraineRussia crisis in 2014 and 2015 (see Figure 8).

From the wider perspective of cultural studies, sharing memes is a significant social practice of redistributing culture texts that may reproduce and/or question dominant ideologies. The experience of using internet memes provides people with pleasures of creative cultural and media consumption and this is clearly an ideological practice. As ideology

$[\ldots]$ is the naturalization of a particular historical cultural articulation. (Grossberg, 1986, p. 67)

2 The diagnosis of merging modalities of civic engagement, political activity and participation in popular culture is of course older than internet memes themselves (Bennett, 2003; Dahlgren, 2001, 2003; Axford, 2001). Therefore internet meme can be perceived as essentially postmodern cultural (media, political) object. 


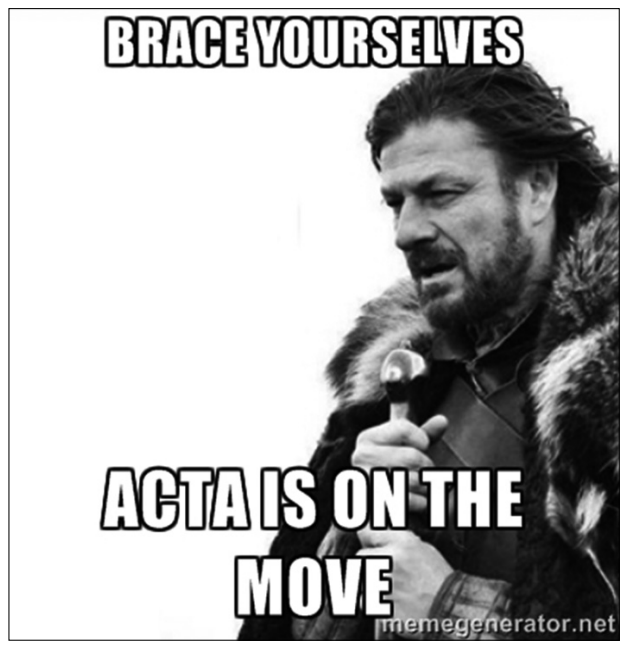

Figure 7. Imminent Ned memes as political commentary (Acta is on the move)

Source: http://memegenerator.net/instance/55995700 (retrieved February 15, 2015).

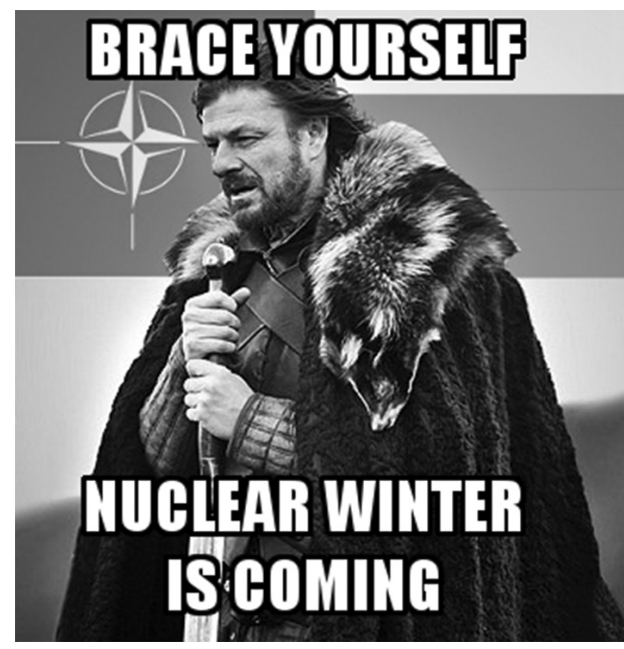

Figure 8. Imminent Ned memes as political commentary (Nuclear winter is coming)

Source: http://knowyourmeme.com/photos/795608-imminent-ned-brace-yourselves-winter-is-coming (retrieved February 15, 2015).

Ideological practices are those through which particular relations, particular chains of equivalences, are "fixed", "yoked together" by undisputed (and often subconscious) validation by common sense. Therefore, while:

[...] memes are seemingly trivial and mundane artifacts, they actually reflect deep social and cultural structures. (Shifman, 2014, p. 15)

My claim here is not that they should be a subject of academic interest despite them being trivial, naive, or sometimes vulgar. Instead, as tied to ideological practices, they should be a subject of academic interest because they are trivial, naive, or sometimes vulgar.

\section{WHY STUART HALL?}

Although the academic discourse on internet memes is still quite sparse, it does include insightful works in the cultural studies approach (Jenkins et al., 2013; Shifman, 2011, 2014). It does not, however, refer to Hall's (1999) encoding/decoding model introduced in 1973, which - as I argue below - can be a very useful analytical tool for theorizing internet memes and online popular cultures in general.

Hall was a very influential theorist for media studies as he was credited with helping develop modern audience studies and theoretical explorations of connections between popular culture and media. Influenced by such different theoreticians as Williams, Gramsci, Althusser and Foucault, Hall's theory links a cultural- 
ism that focuses on the significance of individual and group cultural experiences, and the economic reductionism of post-Marxist critical studies. His work was ahead of its time, linking semiotic studies of active audiences with the political economy of media and poststructuralist thought on relations between discourse, power, and ideology ${ }^{3}$ (Grossberg, 1986; Sparks, 1989; Kellner, 2002).

I am especially interested in Hall's seminal encoding/decoding model, sometimes dubbed the model of program as meaningful discourse. Departing from the classic semiotic approach of Barthes and Eco, Hall inserts a semiotic paradigm into a social framework (During, 1999, p. 507) and thus, when analyzing television discourse, he combines the micro-approach of deep investigation of how particular media texts' ideologies are negotiated and reproduced (within frameworks of knowledge) with the macro-approach of focusing on systemic, structural factors (relations of production and technical infrastructure) that discursively contextualize mass media communication:

Hall proposes a model for media studies that combines media consumption analysis with academic investigation of systemic factors involved, e.g., like cultural, economic, and political processes. Morley, a theorist of media audiences who continued Hall's studies, says that audience studies always go beyond what the name suggests:

I was never, in fact, particularly interested in either television or audiences themselves, as objects of study. What I was interested in was the question of cultural power. The choice to make an empirical study of television audiences was simply a way to "operationalize" a study of the extent (and limits) of ideological or cultural hegemony, as manifested in the forms of media consumption. (Jin, 2011, p. 127)

Apart from his strong focus on the issue of hegemony in practice, a distinctive feature of Birmingham School studies, Morley picks up Hall's idea of joining studies on the daily (common) experience of media with investigations of regulatory and production factors. In other words, meaningful discourse of a media program means taking into account both the political economy of media and people's individual preferences with their social/political/economical contexts. From this perspective, media studies clearly follow the key cultural studies' methodological claim that a researcher:

[...] should not stop at the border of a text, but should see how it fits into systems of textual production, and how various texts are thus part of systems of genres or types of production, and have an intertextual construction - as well as articulating discourses in a given socio-historical conjuncture. (Kellner, 2002, p. 43)

3 Stuart Hall, in critical analyses of Althusser's and Gramsci's thought, considers class factors as important for how society works. However, as Colin Sparks (1989) argues, in his late publications (especially in Policing the Crisis, 1979), Hall quits, yet with no open declarations, Marxist economic reductionism. 


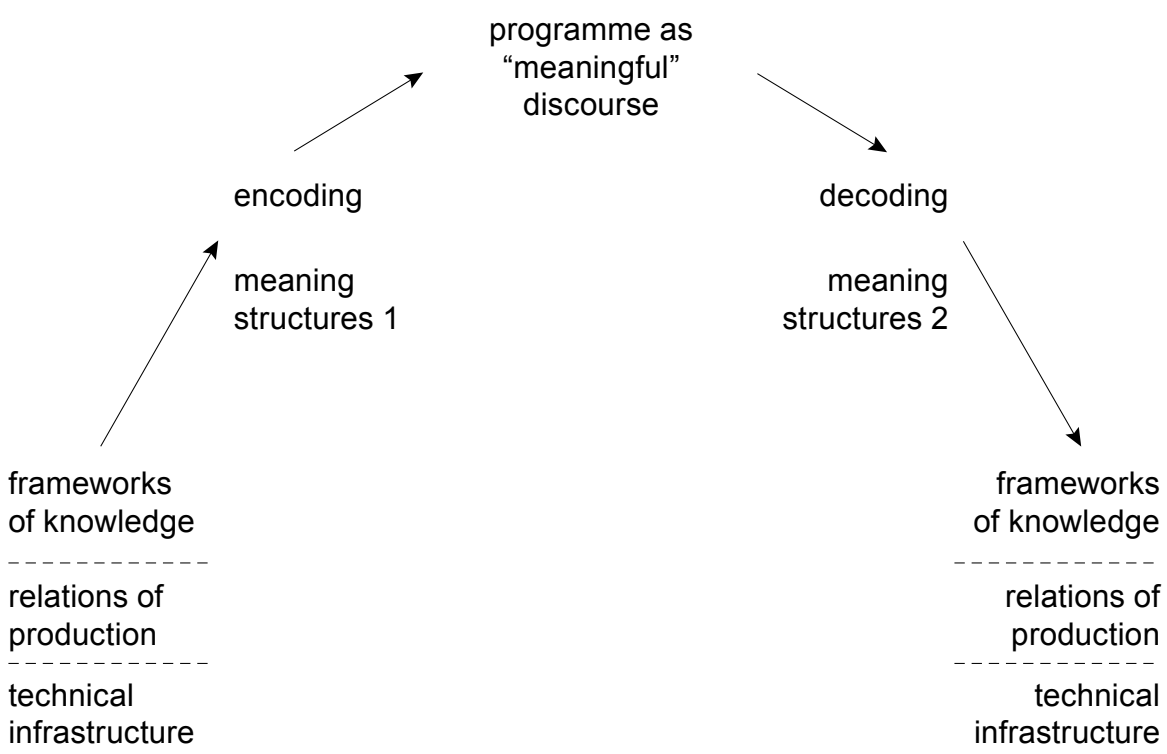

Figure 9. Hall's model of program as "meaningful" discourse

Source: Hall (1999, p. 510).

When applied to studies of new media, it means that finding particular essential (or inherent) characteristics of digital media technologies (like intertextuality, mobility, multimodality, and others) is only part of the job done, although, of course, a necessary one. Studies of particular social practices of new media in particular contexts (Hall could write: in particular historical moments) are absolutely crucial here, as determinations other than technological ones very often make a difference. This approach, strongly influenced by Hall's considerations, is part and parcel of modern media studies methodologies, like those of Couldry (2004) theorizing media as practice, or Gitelman's (2006) concept of social protocols supporting media technologies.

While this is not the place for detailed remarks on Hall's model, several additional remarks will be made when analyzing appropriating the model for studies of internet memes.

\section{APPROPRIATING THE MODEL 1: ON (VANISHING) AUTHORSHIP AND (MULTI) PARTICIPATION}

First, a few general remarks concerning Hall's model: when appropriated to theorizing internet meme, the model underlines the very key aspects of popular cultures online. Hall's (1999) theory of communication accompanying the introduction of the model comprises a four-stage chain of discourse: production, circulation, use (distribution and consumption), and reproduction. The model not only offers an 
analytically useful sequence of activities describing how media texts are used online today (including Hall's great intuition on perceiving distribution and consumption together, which is applicable now more than ever), but also imposes necessary questions about cultural, technological, and economic conditions shaping new media as discursive spaces of participation in popular cultures.

Hall's approach, when applied to the analysis of popular discourse of internet memes, induces taking under consideration a peculiar combination of various modalities. Technical infrastructure (all those new media mentioned above) is no longer a threshold for social agents: when your computer allows you to do almost anything with all the items you can find online, it is other factors that gain importance: popular frameworks of knowledge and relations of production shaping encoding/decoding of internet memes. They comprise a very complicated system that consists of the economic interests of market agents - traditional (movie and music producing companies, mainstream media) and new (content companies of Silicon Valley) culture industries; Intellectual Property Rights (IPR) regimes and policies; subversive and counter-cultural modalities negotiating IPR regimes and re-appropriating their key symbols (like bottom-up popular redefinitions of "piracy"); and, finally, particular social practices - resulting from online services, norms imposed, and users' interests and needs.

It means that whereas internet memes are acts of negotiated readings of seemingly endless mainstream media and culture texts (as people produce and propagate memes about and made of almost anything), each meme consists of a relatively coherent semiotic proposal that is a part of meaningful discourse of online popular culture. And this is, by the way, another good reason for studying internet memes: they are like a lens focusing and magnifying a wide array of cultural phenomena of online popular culture(s).

Undisputedly, one of the most important aspects of internet memes is the very complicated status of their authorship. As Shifman (2014) shows, when writing on internet memes, more convenient than authorship and usage is to use the term multiparticipant - one that encapsulates both to a large extent.

The central part of Hall's theory are his remarks on the effects of formal subrules of [televisual] discourse are in dominance. His theory has challenged traditional models of television-mediated communication, yet some remarks are universal enough to be effectively applicable to analyses on discourses of other media, including popular discourses of the internet.

Hall emphasizes that his approach does not eliminate the significance of the encoding process. Production constructs the message, it consists of its discursive aspects, so it is framed:

[...] throughout by meanings and ideas: knowledge-in-use concerning the routines of production, historically defined technical skills, professional ideologies, institutional knowledge, definitions and assumptions, assumptions about the audience. (Hall, 1999, p. 509) 
Internet memes, just like many other pop cultural online texts, are not produced directly by market or institutional agents (like companies or political parties ${ }^{4}$ ), they are created by common users. On a formal level they are often visual remixes or mash-ups of already existing media texts (like photographs, movie screenshots and whole, music videos, posters etc.) that are collectively produced and distributed online. Therefore, they are a hybrid form of media content, combining indirect authorship by the culture industry (producers of all these movies, cartoons, songs, videos, arcade games, comic-books, television shows etc.) and direct authorship by the active media audiences that reproduce these culture products with digital tools in order to create new meanings (possible readings) and propagate them horizontally across the internet. Referring to the Imminent Ned meme example: it consists of countless visual appropriations of a copyrighted HBO franchise that were performed by anonymous internet users.

This process goes well beyond just an erosion of divides between media production and consumption: it blurs the distinctions between other aspects (and agents involved) of media content dispersal. This proves Benkler's (2006, p. 68) good intuition that what the internet is permitting is much greater disaggregation of the key functions of message production, publishing, and providing credibility. The process makes internet memes online content of a new kind, a multiparticipant one. This is a completely new modality of experiencing media (and culture), for which the term audience has suddenly become strikingly unsuitable.

Last, the meaningful discourse of internet meme comprises a peculiar reversal of the connection between institutions of credibility and authorship. Motivations for producing memes vary greatly. This is not the place to go into detail, but we can say they range from ludic pleasures (messages created and distributed for the lulz - as the popular internet saying states), through collective re-elaboration of common (pop)cultural identities, to serious citizen and political commentary and resistance (Jenkins et al., 2013; Gilbert, 2013; Shifman, 2014; Nowak, 2013a, 2013b). All of these, however, are by all means common in the term's meaning given by Raymond Williams (1958): they connote ordinary, everyday cultural practices, therefore they belong to the cultural (and political) sphere of the popular; and are one of the popular commons, understood here as a resource over which the whole society should have access and use rights (Boyle, 2008, p. 38).

This negotiative bottom-up nature of internet meme has become an inherent part of its generic characteristics and is strictly connected to the meme's unknown authorship as one of its key signifiers. Not only it is irrelevant who produces a particular meme, but it should not be revealed. Authorship does not operate in the sphere of internet memes, they should remain anonymous, just like in the popular

4 Internet memes can be, however, produced by institutional or market agents but then they are not true memes (they do not connote the set of meanings reviewed in the paper), at least they are not perceived as such. 
concept of Anonymous, in which a masked figure from the $V$ for Vendetta graphic novel (written by Moore and illustrated by Lloyd) connotes anti-hegemonic values of bottom-up internet-based hacktivist resistance (Jacobsen, 2008). This concept of anonymous and the popular appraisal of online anonymity was originated within seminal counter-cultural communities, for example, the 4 chan.org website, that supports a broad - yet coherent - set of values and meanings including: resisting institutional and corporate forces, anarchistic and subversive fun, freedom of speech and right to privacy (Jacobsen, 2008). Therefore, any piece of Imminent Ned meme could not be convincing (no matter the subject) if it was released (at least openly) by the HBO Company. These images are credible as long as they contain claims or commentary perceived by its audiences as peoples.

This positive perception of anonymity is coherent with the open source software development model (Benkler, 2006; Berry, 2008) linking together ideas of collaborative contribution to community-oriented approach and values. This ideological coherence makes internet memes popular culture artifacts supporting claims of anti-IPR movement, as an internet meme connotes a liberal approach towards copyright by its peculiar mode of production.

\section{APPROPRIATING THE MODEL 2: POLITICAL ECONOMY OF INTERNET MEMES}

While each stage of Hall's chain of discourse (production, circulation, use distribution and consumption, reproduction) is relatively autonomous from the others, when speaking of how messages are meaningfully de-coded, "polysemy must not [...] be confused with pluralism" (Hall, 1999, p. 513) as each stage of this chain limits interpretation possibilities of the following.

The meaning of coding, understood as a process of co-shaping messages' readings, has changed in the new media environments. In online popular cultures these four stages of circuit are more dispersed and less connected to each other than ever before and the level of possible polysemy rises, because the social contexts of how and where memes are read and redistributed are widely diverse. This meme's relative autonomy from the moment of production is also a part of its generic ideology. As Hall notes:

[...] circulation and reception are, indeed, moments of the production process [...] and are reincorporated, via a number of skewed and structured feedbacks, into the production process itself. (1999, p. 509)

Here this potential decontextualization of a meme's reception can be perceived as another layer of meaning in the meaningful discourse of internet memes as popular online content. It also reveals how in the market level (relations of production + technical infrastructure) internet memes are embedded in a peculiar way in today's culture industry: 1) memes' producers often use representations from all possible kinds of sources, ranging from culture industry products to user-generat- 
ed content; 2) the infrastructure for memes' distribution and reproduction are services offered by content companies - the new culture industry, often interested in liberating IPR regimes, as they often seek to monetize any users' activities.

An Internet meme is thus a media item typical for both its time and

[...] a world where mass content is continually repositioned as it enters different niche communities. [...] As material spreads, it gets remade: either literally, through various forms of sampling and remixing, or figuratively, via its insertion into ongoing conversations and across various platforms. This continuous process of repurposing and recirculating is eroding the perceived divides between production and consumption. (Jenkins et al., 2013, p. 27)

I discussed the erosion of this division earlier. Here I would like to refer to another aspect of the issue. The hybrid status of internet memes reveals clearly that the old (and good - as it was pretty simple) division into culture industry and consumers-true creators of popular cultures, is no longer valid. There is an important change we witness today: along with traditional culture industry (comprising mainstream media, movie and music companies etc.) a new, digital one, has emerged (software- and so called content companies like Apple, Facebook, Google) and quickly gains a stable market position by seeking to capitalize online content flows (Lobato et al., 2011; May, 2010; Zittrain, 2008).

Therefore, the development of new media has been both constrained and encouraged by legal, social and discursive practices associated with liberalization or preservation/extension of intellectual property rights (Lister et al., 2009, p. 189; May \& Sell, 2006). Unconstrained digital reproduction and distribution of copyrighted material have triggered a reaction from the traditional culture industry seeking to control intellectual and cultural goods by policies aiming to constrain unwanted practices by introducing legal and social normative systems (May, 2007, 2010; Smith, 2013). Copying and distributing copyrighted material is thus officially stigmatized and criminalized within the hegemonic discourse of piracy (Mylonas, 2011). On the most general level, these dynamic relations among two industries are one of the key processes shaping modern neoliberal economies. As they also shape structural, economic, and legal conditions of the popular usage of new media, they are inherent constituents of relations framed by Hall in his encoding/decoding model. An Internet meme, from this perspective, is a popular media content produced and used by common internet users that - usually - supports new culture industry strategies (horizontal flows of online media content) and - usually impairs economic and legal goals of the traditional culture industry by violating legal and discursive framework of the copyright regime (see Figure 10).

The model, which I propose here, is obviously not flawless, as it is quite simplistic. It highlights, however, one of the crucial aspects of online popular cultures: three groups of agents, visualized by three columns, involved - completely different in terms of their motivations and market positions. This split of the culture industry into old and new is a profound one - as it leads to a need for interesting 


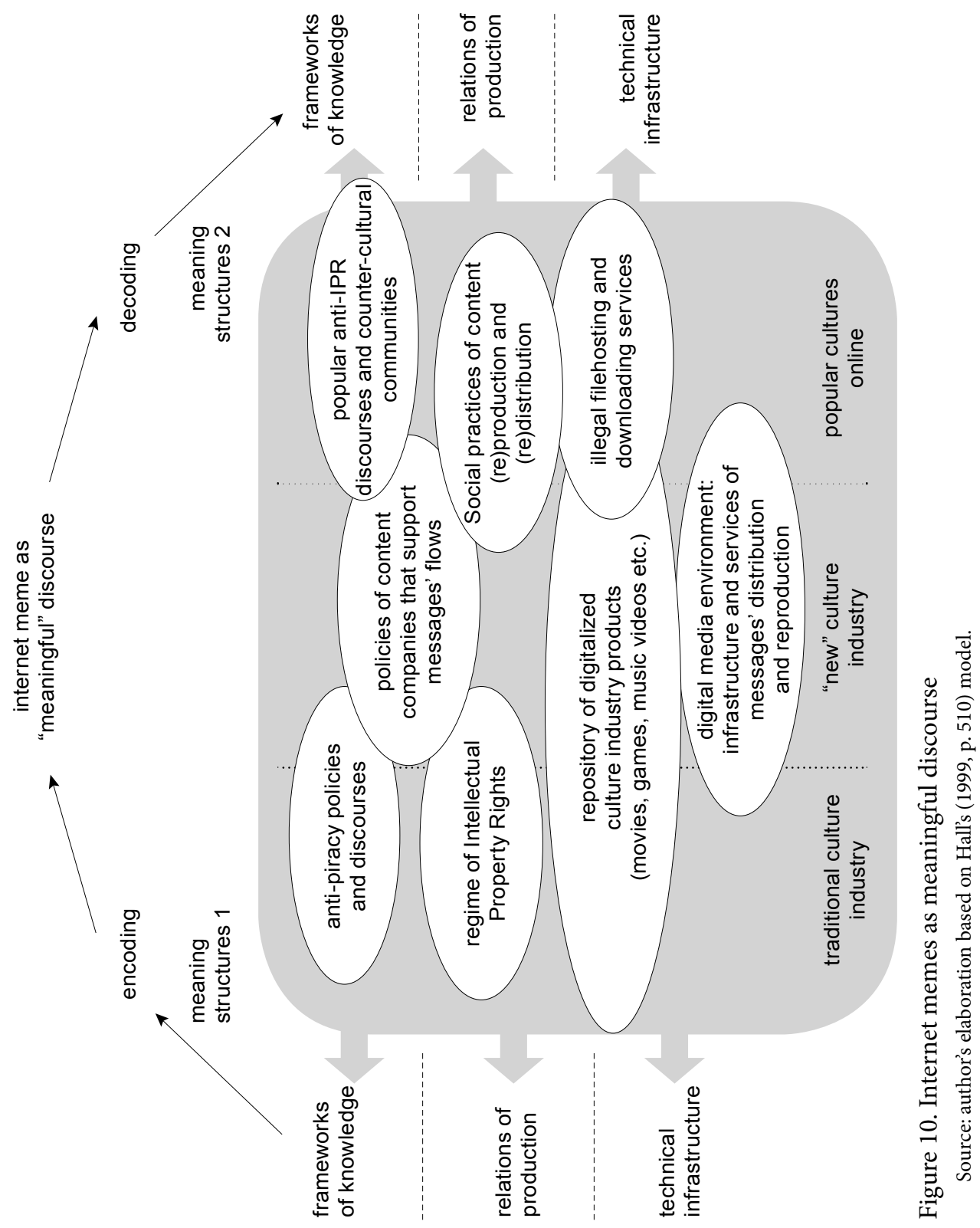

theoretical adjustments: the emergence of the new digital industry of content companies cancels, at least to some extent, the traditional theoretical analog-worlddivision between one entity of the culture industry (with its strategies) and the realm of the people and their tactics as portrayed in seminal works of de Certeau (1984) or Fiske (1989). 


\section{CONCLUDING REMARKS: THE MODEL REVISITED}

Therefore, instead of that simple binary division between industry and the peopleaudiences-consumers, we face today a new triad of agents composing a completely new system that reveals highly complex sets of interests, strategies, policies and actions that will probably be anything but constant. It makes us - again - take into consideration as many particularities (practices, contexts, historical moments) as possible; new media have become a technology for cultural (political) articulations performed by unstable political and economic coalitions of agents of various kinds. And internet memes are both a perfect example of hybrid media content epitomizing the unstable nature of modern popular culture and media systems, and a cultural medium that may reflect these contradictions and tensions, when they speak of, for instance, issues of piracy, legislation aimed at extending intellectual property rights regimes like ACTA or SOPA.

I hardly mentioned the latter aspect of internet memes, that is how they reflect particular social, cultural, political conditions. I clearly did not focus on internet memes' possible uses, on how they work in particular contexts and what social, cultural, citizen, consumer, or political functions they may serve. This article was more interested in finding the lowest common denominator for that what is discursively embedded in any internet meme, because it is an internet meme. In other words, I try to extract its characteristics as a media genre or a kind of internet language (although obviously neither of these words is fully accurate), and, by doing so, to tell something about how online popular cultures work today.

Hall's model turns out to be a useful analytical tool when conceptualizing internet memes as meaningful discourse. The meme concept itself is good introduction to diagnoses of wider perspectives. To let Shifman speak again, the concept of an internet meme:

$[\ldots]$ is not only useful for understanding cultural trends: it epitomizes the very essence of the socalled Web 2.0 era. (2014, p. 15)

The mission, then, is far from accomplished, and this article is a mere starting point for further research, as it consists of identification of new topics more than conclusions. However, the tool for further studies - Hall's model elaborated more than 40 years ago - looks surprisingly ready and applicable.

\section{REFERENCES}

Axford, B. (2001). The transformation of politics or anti-politics? In: Axford, B., Huggins, R. (eds.). New Media and Politics. London: Sage, pp. 1-29.

Benkler, Y. (2006). The Wealth of Networks. How Social Production Transforms Markets and Freedom. London and New Haven: Yale University Press. 
Bennett, L. (2003). Lifestyle politics and citizen-consumers. Identity, communication and political action in late modern society. In: Corner, J., Pels, D. (eds.). Media and the Restyling of Politics. London: Sage, pp. 137-150.

Berry, D.M. (2008). Copy, Rip, Burn: The Politics of Copy Left and Open Source. London: Pluto Press. Blackmore, S. (1999). The Meme Machine. Oxford: Oxford University Press.

Boyle, J. (2008). The Public Domain. Enclosing the Commons of the Mind. London and New Haven: Yale University Press.

Burgess, J., Green, J. (2009). YouTube: Online Video and Participatory Culture. Cambridge: Polity Press.

Couldry, N. (2004). Theorising media as practice. Social Semiotics, 14 (2), pp. 115-132.

de Certeau, M. (1984). The Practice of Everyday Life. Los Angeles: University of California Press.

Dahlgren, P. (2001). The transformation of democracy? In: Axford, B., Huggins, R. (eds.). New Media and Politics. London: Sage, pp. 64-88.

Dahlgren, P. (2003). Reconfiguring civic culture in the new media milieu. In: Corner, J., Pels, D. (eds.). Media and the Restyling of Politics. London: Sage, pp. 151-170.

Dawkins, R. (1976). The Selfish Gene. Oxford: Oxford University Press.

During, S. (1999). Editor's introduction. In: During, S. (ed.). The Cultural Studies Reader. London and New York: Routledge, p. 507.

Fiske, J. (1989). Understanding Popular Culture. London: Routledge.

Gilbert, Ch. (2013). Playing with Hitler: Downfall and its ludic uptake. Critical Studies in Media Communication, 1, pp. 1-18.

Gitelman, L. (2006). Always Already New. Media, History, and the Data of Culture. Cambridge: MIT Press.

Grossberg, L. (1986). History, politics and postmodernism: Stuart Hall and cultural studies. Journal of Communication Inquiry, 10 (2), pp. 61-77.

Hall, S., Critcher, Ch., Jefferson, T., Clarke, J., Roberts, B. (1979). Policing the Crisis: Mugging, the State and Law and Order. London: Macmillan Press.

Hall, S. (1997). Representation: Cultural Representations and Signifying Practices. London: Sage.

Hall, S. (1999). Encoding, decoding. In: During, S. (ed.). The Cultural Studies Reader. London and New York: Routledge, pp. 507-517.

Jacobsen, J. (2008). We Are Legion: Anonymous and the War on Scientology. Retrieved September 15, 2014 from http://www.lisamcpherson.org/pc.htm.

Jin, H. (2011). British cultural studies, active audiences and the status of cultural theory. An interview with David Morley. Theory, Culture \& Society, 28 (4), pp. 124-144.

Jenkins, H. (2006). Convergence Culture: Where Old and New Media Collide. New York: New York University Press.

Jenkins, H., Ford, S., Green, J. (2013). Spreadable Media. Creating Value and Meaning in a Networked Culture. New York: New York University Press.

Kellner, D. (2002). The Frankfurt school and British cultural studies: The missed articulation. In: Nealon, J., Irr, C. (eds.). Rethinking the Frankfurt School. Alternative Legacies of Cultural Critique. New York: New York University Press, pp. 31-58.

Lessig, L. (2008). Remix. Making Art and Commerce Thrive in the Hybrid Economy. London: Bloomsbury.

Lister, M., Dovey, J., Giddings, S., Grant, I., Kelly, K. (2009). New Media. A Critical Introduction. London and New York: Routledge.

Lobato, R., Thomas, J., Hunter, D. (2011). Histories of user-generated content: Between formal and informal media economies. International Journal of Communication, 5 (1), pp. 899-914.

May, C. (2007). Digital Rights Management: The Problem of Expanding Ownership Rights. Oxford: Chandos Publishing.

May, C. (2010). The Global Political Economy of Intellectual Property Rights. London: Routledge. 
May, C., Sell, S.K. (2006). Intellectual Property Rights: A Critical History. Boulder: Lynne Rienner.

Mylonas, Y. (2011). Accumulation, control and contingency: Towards a critical understanding of intellectual property rights' 'piracy'. First Monday, 16, pp. 12-15. Retrieved February 15, 2015 from http://firstmonday.org/ojs/index.php/fm/article/view/3709.

Nowak, J. (2013a). Memy internetowe: teksty (cyfrowej) kultury językiem krytyki społecznej [Internet memes: Digital culture texts as language of social critique]. In: Hofman, I., Kępa-Figura, D. (eds.). Współczesne media. Język mediów. Lublin: Wydawnictwo UMCS, pp. 227-238.

Nowak, J. (2013b). Political communication, social media and popular culture: The adisucks Facebook protest case study. In: Dobek-Ostrowska, B., Garlicki, J. (eds.). Political Communication in the Era of New Technologies. Frankfurt am Main: Peter Lang Publishing Group, pp. 127-146.

Shifman, L. (2011). An anatomy of a YouTube meme. New Media \& Society, 14 (2), pp. 187-203.

Shifman, L. (2014). Memes in Digital Culture. Cambridge: MIT Press.

Smith, P.J. (2013). Speaking for freedom, normalizing the net? Journal of Information Technology \& Politics, 10 (4), pp. 423-443.

Sparks, C. (1989). Experience, ideology, and articulation: Stuart Hall and the development of culture. Journal of Communication Inquiry, 13, pp. 79-87.

Williams, R. (1958). Culture and Society. London: Chatto and Windus.

Zittrain, J. (2008). The Future of the Internet. And How to Stop It. New Haven: Yale University Press. 